\title{
PENGARUH VARIASI SAMBUNGAN PADA CRASH BOX MULTI SEGMEN TERHADAP KEMAMPUAN PENYERAPAN ENERGI DENGAN UJI QUASI STATIC
}

\author{
Halman ${ }^{1}$, Moch. Agus Choiron ${ }^{2}$, Djarot B. Darmadi ${ }^{3}$ \\ ${ }^{1}$ Jurusan Teknik Mesin PDD Politeknik Negeri Nunukan \\ 2,3Jurusan Teknik Mesin Universitas Brawijaya Malang \\ JL. MT. Haryono 167 Malang 65145, Indonesia \\ Email : halmandini66@gmail.com
}

\begin{abstract}
Along with the elevating number of cars, accidents due to car crashes are increasing. Therefore, technology is needed to reduce the occurrence of the drivers' injuries. Crash box is one of the potential passive safety technology which is widely observed today. Crash box is installed between bumper and chassis, aims to reduce the cassualties when the car crashes. In this article, crash box research was conducted by real experimental method through quasi-static test to evaluate the energy absorption capability of circular-shaped multi-segment crash box. Crash box material was made from aluminum A6063. The connection on each segment is a chamfer with $45^{\circ}$ angle. The connections between segments 1 and 2 were varied with 3 connection models, those are 1/4, 1/3 and 1/2 of the total length, i.e.120 mm. The results of the study showed that, the highest energy absorption obtained from the crash box with connection of $1 / 2$ and the energy absorption is $5249.726 \mathrm{~J}$. Crash box type of $1 / 4$ and 1/3 exhibit energy absorption of $3886.238 \mathrm{~J}$ and $3106.027 \mathrm{~J}$ respectively. Generally, the deformation pattern on the crash box is mixed-mode (axisymmetric-diamond).
\end{abstract}

Keywords: Multi-Segment Crash Box, Quasi-Static Test, Energy Absorption

\section{PENDAHULUAN}

Dalam dekade terakhir pada tahun 2010 sampai dengan 2014 penggunaan mobil pribadi mengalami peningkatan yang cukup pesat sebesar $9,11 \%$ hal ini diikuti dengan meningkatnya jumlah kecelakaan yang menyebabkan pengemudi mengalami cedera [1]. Crash box adalah salah satu teknologi sistem keselamatan pasif yang telah banyak dikembangkan. Crash Box berfungsi sebagai penyerap energi kinetik pada saat mobil mengalami benturan atau terjadi kecelakaan, baik benturan dari depan maupun dari belakang. Perangkat komponen crash box didesain untuk mengurangi terjadinya gaya yang terjadi ke seluruh body kendaraan selama mengalami tabrakan. Sehingga perangkat crash box di pasang diantara penyangga dan rangka kendaraan [2]. Penggunaan crash box yang banyak digunakan antara lain berbentuk lingkaran (circle), persegi (square), dan persegi panjang (rectangular). Jenis crash box yang berbentuk lingkaran mempunyai nilai penyerapan energi paling besar [3].

Pada umumya material yang digunakan dalam pembuatan crash box adalah aluminium dimana mempunyai karakteristik yang ringan, tahan korosi dan mempunyai nilai keuletan yang tinggi serta dengan kemampuan permesinan yang baik [4].

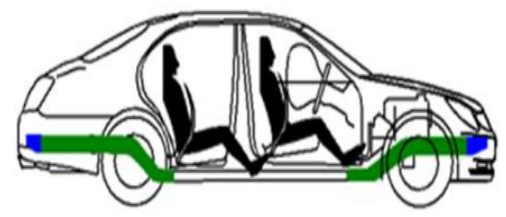

Crash box

Frame

Gambar 1 Komponen Crash Box pada Mobil

Dari berbagai penelitian yang telah dilakukan pada crash box dengan kecepatan tumbukan yang telah ditentukan terjadi adanya perubahan deformasi plastis. Hal ini menunjukkan terjadinya penyerapan energi pada crash box tersebut. Akan tetapi di peroleh fenomena bahwa, makin cepat perubahan deformasi plastis pada crash box, maka sisa kecepatan akibat tumbukan masih 
tersisa tinggi yang dapat membahayakan rangka utama kendaraan, sehingga keamanan bagi pengemudi dianggap masih rendah [5]. Mengatasi permasalahan tersebut maka dibuat crash box multisegmen. Crash box multisegmen dapat menyerap energi kinetik melalui gesekan antara segmen satu dengan segmen lainya sehingga sebagian energi dapat diserap sebelum terjadinya deformasi [6].

Prinsip kerja dari crash box ini adalah dengan menyerap energi yang tinggi melalui masuknya segmen satu dengan segmen yang lainya karena adanya gaya gesek. Selanjutnya apabila energi tumbukan masih besar maka dilanjutkan ke tahap deformasi pada crash box sehingga membentuk beberapa pola deformasi antara lain Concertina, Diamond dan Mixed-mode atau gabungan dari pola concertina-diamond (axisymmetric-diamond) [7].

Dari literatur diatas, maka dilakukan penelitian lebih lanjut dengan menambahkan dan mengatur sambungan segmen pada crash box dengan tujuan untuk meningkatkan inersia dan mengurangi fenomena adanya buckling yang terjadi pada saat terjadinya pembebanan aksial sehingga diperoleh kemampuan penyerapan energi yang lebih maksimal dan membentuk pola deformasi yang lebih baik $[8,9]$.

\section{METODOLOGI PENELITIAN}

Dalam penelitian ini dilakukan secara eksperimental, dengan melakukan uji quasi statik pada crash box untuk mengetahui secara langsung nilai penyerapan energi yang diserap pada masing-masing model sambungan crash box. Crash box dibuat dua segmen berbentuk lingkaran dengan ketebalan 1,2 $\mathrm{mm}$ dan panjang $120 \mathrm{~mm}$ menggunakan material aluminium tipe A6063. Pada masing-masing ujung sambungan diberikan sudut chamfer sebesar 45․

Variabel yang digunakan pada penelitian ini adalah dengan membuat model sambungan pada crash box dengan variasi model sambungan 1/4, 1/3 dan 1/2. Model sambungan pada crash box dapat dilihat pada Gambar 2.

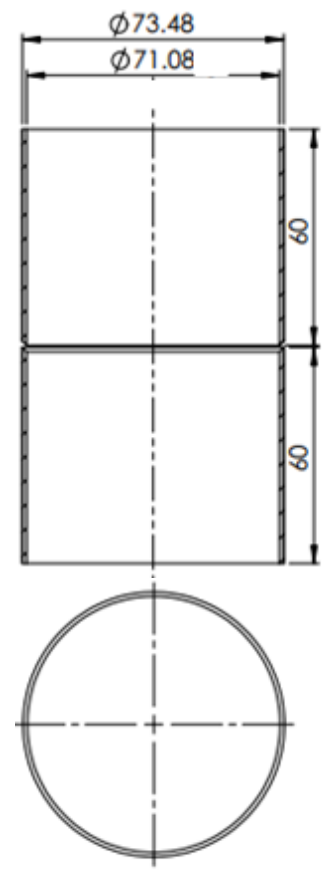

(a)

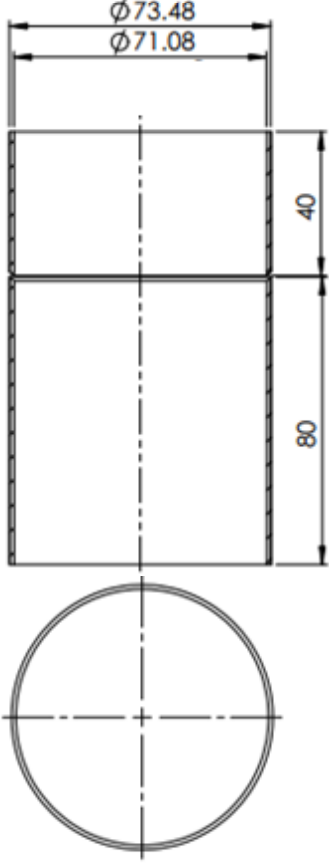

(b)

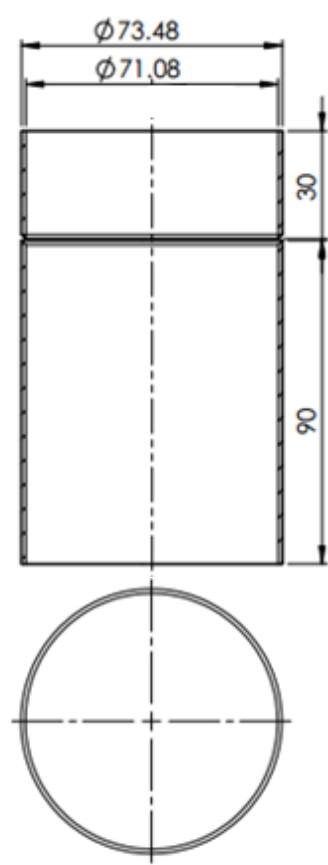

(c) 
Gambar 2 Variasi Model Sambungan Crash Box (a) Model Sambungan 1/2

(b) Model Sambungan 1/3 (c) Model Sambungan 1/4

\section{HASIL DAN PEMBAHASAN}

\section{Force Reaction}

Force reaction adalah gaya yang diberikan oleh crash box sebagai reaksi untuk menahan beban oleh impactor. Force reaction pada crash box setelah dilakukan uji quasi statik dapat dilihat pada Gambar 3.

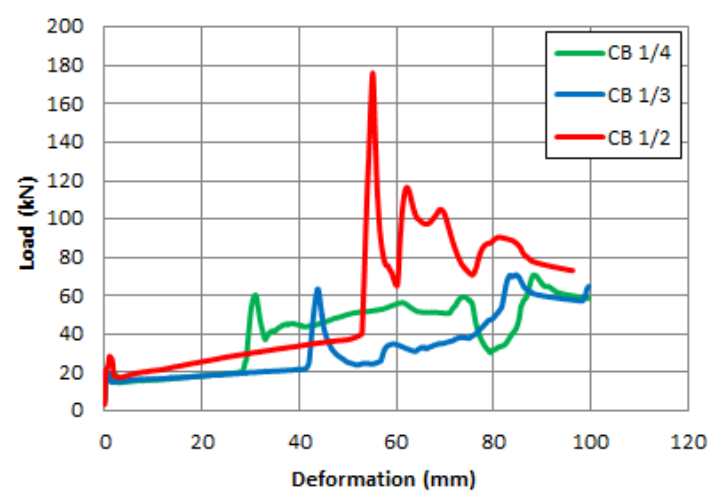

Gambar 3 Hubungan Gaya dan Deformasi pada Sambungan Crash Box

Pada Gambar 3 diketahui hubungan antara beban (load) dengan deformation pada masing-masing sambungan crash box. Secara umum dapat dilihat bahwa, folding pada crash box terjadi terlebih dahulu dialami oleh crash box yang salah satu segmennya lebih panjang dari crash box lainya. Hal ini disebabkan oleh panjang kolom yang berbeda oleh masing-masing jenis sambungan crash box. Dimana, kolom yang semakin panjang semakin mudah untuk mengalami buckling (Euler).

Pada awal pembebanan dibutuhkan gaya sebesar 25 sampai $30 \mathrm{kN}$ untuk mendorong tabung segmen satu menembus memasuki area pada tabung segmen dua. Dorongan oleh tekanan dari impactor merupakan fase pertama dimana proses penyerapan energi terjadi dengan cara melalui gesekan antara tabung segmen satu dengan segmen dua[6].

Pada model crash box sambungan 1/2 mempunyai nilai force reaction maksimum tertinggi sebesar 176,166 kN. Displacement pada crash box dimulai dengan adanya gesekan kemudian terjadi beban kejut akibat adanya gabungan gaya dari segmen satu terhadap segmen dua. Selanjutnya crash box mengalami tiga kali folding. Folding pertama pada $54,89 \mathrm{~mm}$, folding kedua pada 61,33 $\mathrm{mm}$ dan folding terakhir terjadi pada 67,48 $\mathrm{mm}$.

Crash box dengan model sambungan $1 / 3$ mempunyai nilai force reaction terendah yaitu sebesar 70,948 kN. Displacement pada crash box dimulai saat adanya gabungan gaya dari segmen satu terhadap segmen dua. Selanjutnya membentuk folding pada 43,65 $\mathrm{mm}$ dan dinding crash box mengalami robek sehingga folding kedua terjadi pada 83,06 $\mathrm{mm}$.

Pada crash box model sambungan $1 / 4$ mempunyai nilai force reaction maksimum sebesar 70,946 kN. Crash box mengalami folding pertama terjadi pada $30,61 \mathrm{~mm}$ selanjutnya crash box mengalami robek dan memanjang membentuk lapisan tambahan pada segmen dua. Akibat dari lapisan tambahan tersebut menyebabkan tebal dinding bertambah, hal ini berdampak pada meningkatnya momen inersia[8]. Oleh karena itu, nilai force reaction rata-rata lebih tinggi jika dibandingkan dengan crash box sambungan $1 / 3$. Hal ini tidak sesuai dengan teori pada persamaan Euler

$$
P_{c r}=\frac{\pi^{2} E l}{4 L^{2}}
$$

Dimana :

$P_{c r} \quad=$ Beban Kritis [N]

$E \quad=$ Modulus Elastisitas [MPa]

I = Momen Inersia Penampang $\left[\mathrm{m}^{4}\right]$

$L \quad=$ Panjang kolom [m]

Persamaan di atas merupakan persamaan untuk mencari beban kritis dari suatu struktur. Beban kritis adalah beban minimal yang dibutuhkan untuk suatu struktur mengalami deformasi. Berdasarkan persamaan tersebut, panjang kolom berbanding terbalik dengan beban kritis. Semakin panjang suatu struktur, maka beban kritisnya semakin kecil.

Pada crash box sambungan 1/2, panjang segmen 1 dan segmen 2 sama, sehingga tidak ada kolom panjang, menyebabkan beban kritisnya besar. Sedangkan pada sambungan $1 / 4$ dan $1 / 3$ mempunyai panjang segmen yang berbeda, sehingga salah satu segmen menjadi kolom panjang yang menyebabkan beban kritisnya kecil. Akan tetapi dari hasil eksperimen diketahui bahwa pada sambungan crash box 
1/4 mempunyai nilai force reaction yang lebih tinggi jika dibandingkan dengan crash box pada sambungan 1/3. Hal ini dikarenakan pada crash box sambungan $1 / 4$ terjadi buckling disertai robeknya dinding crash box segmen 2 dan selanjutnya terbentuk lapisan yang menyebabkan dinding crash box bertambah tebal. Momen inersia menjadi meningkat akibat dari tambahan lapisan tersebut sehingga menyebabkan force reaction menjadi besar[8].

\section{Penyerapan Energi}

Pada saat impactor menghantam crash box, energi impact dari impactor akan dikonversikan menjadi energi regangan yang mengakibatkan perubahan bentuk pada crash box. Energi regangan didapatkan melalui luas daerah di bawah kurva pada Gambar 3, sebagai usaha yang dilakukan impactor sehingga energi regangan diasumsikan hasil konversi energi kinetik dari impactor[5].

Dari Gambar 4 menunjukkan bahwa, penyerapan energi terbesar terjadi pada crash box sambungan 1/2 yaitu sebesar 5249,726 J, selanjutnya pada crash box sambungan 1/4 sebesar 3886,238 J, dan crash box terendah terdapat pada sambungan $1 / 3$ sebesar 3106,027 J. Pada crash box sambungan 1/2 mempunyai nilai penyerapan energi terbesar diantara model sambungan lainnya. Hal ini disebabkan karena pada model sambungan $1 / 2$ mempunyai nilai force reaction (beban) tertinggi diantara model lainnya. Hal ini sesuai dengan persamaan :

$U=W=\int_{0}^{\delta} P(\delta) d \delta$

Dimana :

$\begin{array}{ll}U & =\text { Energi Regangan }[\mathrm{J}] \\ W & =\text { Usaha }[\mathrm{J}] \\ P & =\text { Beban }[\mathrm{N}] \\ \delta & =\text { Perpindahan }[\mathrm{m}]\end{array}$

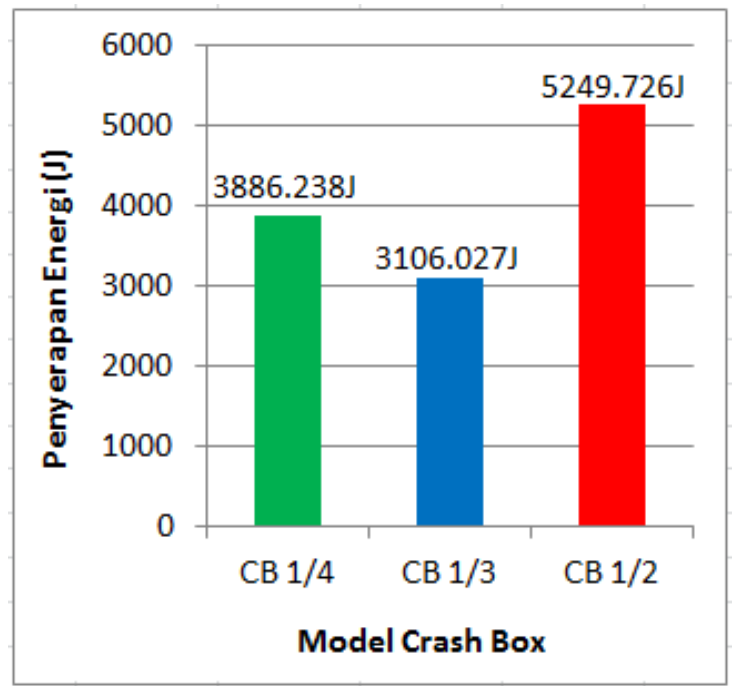

Gambar 4 Penyerapan Energi pada masing masing Sambungan Crash Box

Persamaan dua merupakan persamaan yang digunakan untuk mencari besarnya energi regangan atau usaha. Dari persamaan tersebut diketahui bahwa, nilai energi berbanding lurus dengan nilai beban sehingga semakin besar nilai beban, maka nilai energinya semakin besar pula.

Namun, pada crash box sambungan 1/4 mempunyai nilai penyerapan energi yang lebih tinggi sebesar 3886,238 J jika dibandingkan dengan crash box sambungan 1/3 sebesar 3106,027 J dikarenakan nilai penyerapan energi pada crash box dipengaruhi oleh force reaction dari gaya yang diberikan oleh crash box sebagai reaksi untuk menahan beban. Hal ini sesuai dengan persamaan (2), dimana force reaction atau beban $(P)$ berbanding lurus dengan usaha (W) atau energi regangan (U). Makin besar beban yang terjadi, maka nilai penyerapan energinya makin besar pula[9].

\section{Pola deformasi}

Crash box atau tabung yang berdinding tipis mempunyai kemungkinan tiga pola deformasi yang dapat dialami apabila dikenai pembebanan quasi-static, yaitu concertina (axisymmetric), diamond (non-axisymmetric), dan mixed mode (axisymmetric-diamond). Pola deformasi dan proses terjadinya dari masing-masing model crash box dapat dilihat pada Gambar 5, Gambar 6, dan Gambar 7 berikut: 

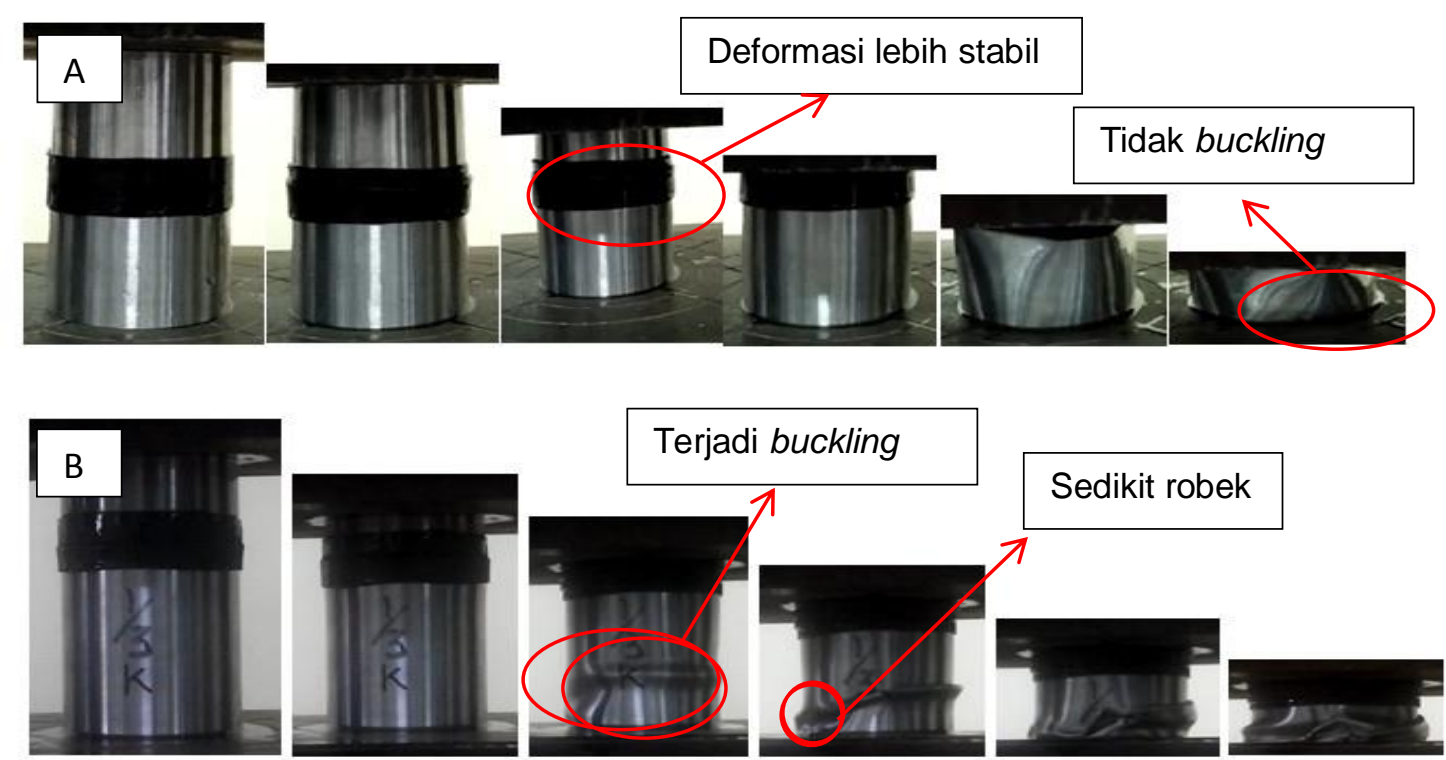

Gambar 5 Pola Perubahan Deformasi Crash box (a) Sambungan 1/2 (b) Sambungan 1/3 (c)
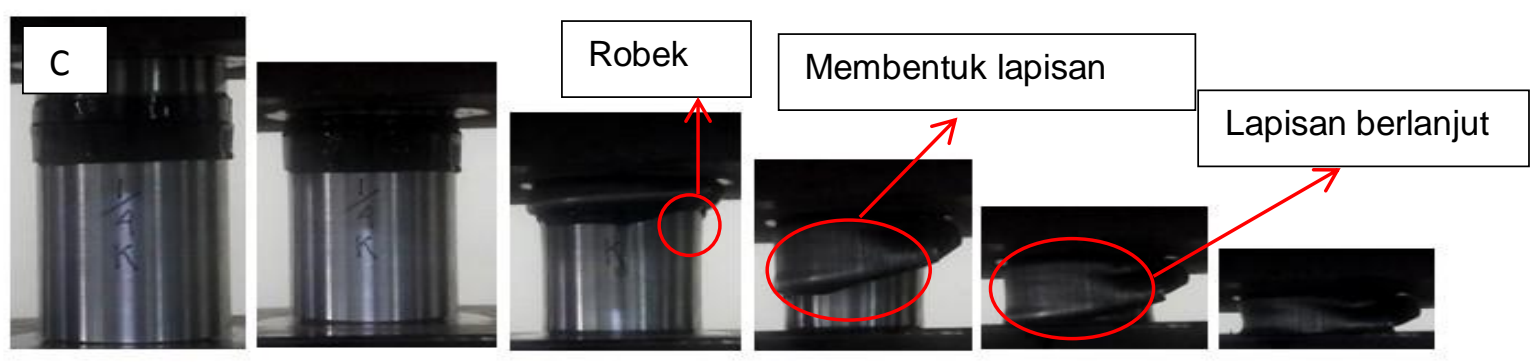

sambungan $1 / 4$
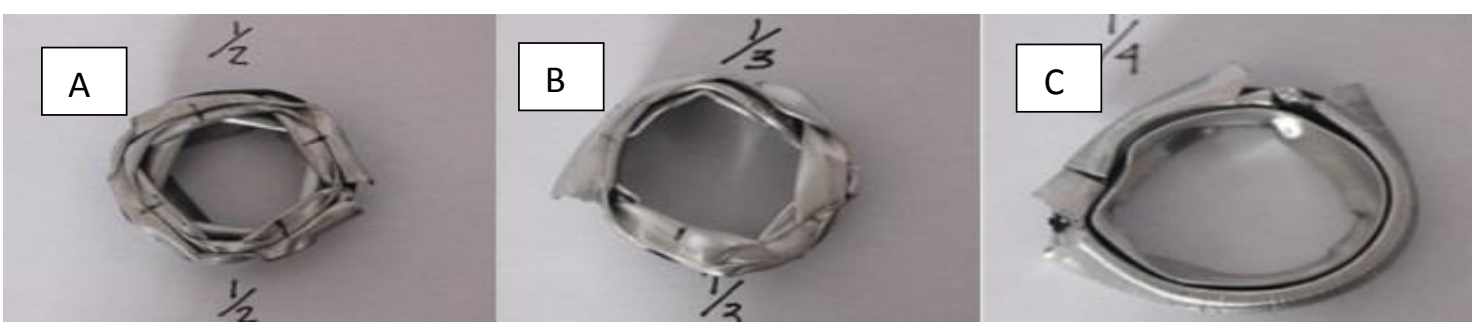

Gambar 6 Pola Deformasi Crash box Tampak Atas (a) Sambungan 1/2 (b) Sambungan 1/3

(c) sambungan $1 / 4$

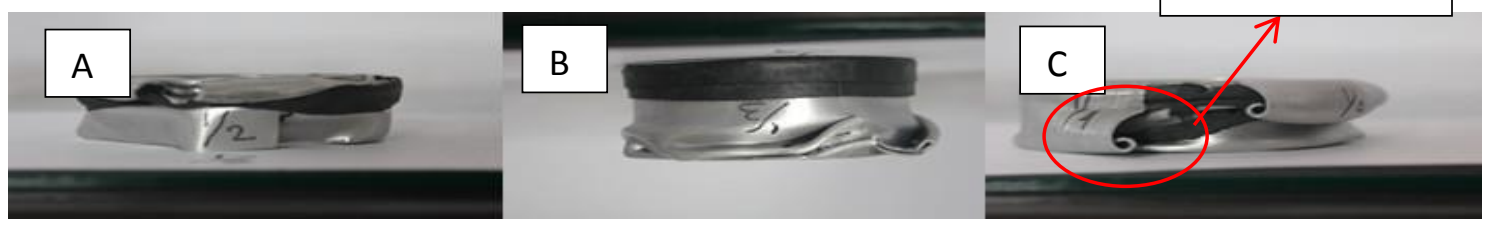

Gambar 7 Pola Deformasi Crash Box Tampak Samping (a) Sambungan 1/2 (b) Sambungan 1/3 (c) sambungan $1 / 4$ 
Dari hasil pengujian didapat bahwa, pada crash box model sambungan 1/4 dan $1 / 3$ terjadi buckling, hal ini karena pada kedua model sambungan tersebut salah satu segmennya mempunyai kolom panjang, sehingga menyebabkan beban kritisnya menjadi kecil karena itu penyerapan energinya tidak dapat bekerja secara maksimal. Pada crash box model sambungan $1 / 4$ dan $1 / 3$ cenderung membentuk pola deformasi model kombinasi atau campuran (mixed-mode) antara axisymetric dan diamond (axisymmetric-diamond). Hal ini disebabkan oleh pengaruh struktur yang tidak stabil karena memiliki segmen yang berbeda, sehingga salah satu segmennya adalah kolom panjang. Hal ini menyebabkan terjadinya buckling yang lebih awal dibandingkan dengan crash box sambungan $1 / 2$ [8].

Deformasi pada crash box $1 / 4$ diawali dengan adanya buckling yang menyebabkan dinding crash box robek memanjang dan terjadi lapisan tambahan memasuki segmen dua sehingga ketebalan crash box menjadi bertambah dan akibatnya berdampak pada meningkatnya momen inersia crash box. Hal ini menyebabkan penyerapan energinya menjadi lebih besar dan melebihi penyerapan energi yang terjadi pada crash box model sambungan 1/3. Pada crash box sambungan $1 / 3$ pola deformasi hampir sama dengan pola sambungan crash box 1/4 akan tetapi pada crash box sambungan $1 / 3$ terjadi robek yang tidak terlalu panjang dan hampir membentuk pola Concertina (axisymmetric).

Dibandingkan dengan crash box model sambungan 1/2 panjang segmen satu dan segmen dua adalah sama, sehingga tidak ada kolom panjang, karena itu deformasi terjadi cenderung lebih stabil dan buckling yang terjadi tidak disertai dengan robeknya dinding crash box pada segmen dua, sehingga menyebabkan penyerapan energinya lebih optimal daripada crash box model sambungan lainnya dengan menghasilkan pola deformasi berbentuk pola mixed-mode (axisymmetricdiamond) [7].

\section{KESIMPULAN}

1. Pengaruh sambungan segmen pada crash box sangat tergantung pada struktur kolomnya. Salah satu segmen dengan struktur kolom panjang lebih cenderung akan mengalami buckling sehingga beban kritisnya menurun dan akibatnya, kemampuannya untuk menyerap energi tidak optimal. Hal ini diperoleh pada crash box model sambungan $1 / 3$ dan sambungan $1 / 4$, dimana kedua model sambungan tersebut mengalami buckling, berbeda dengan crash box sambungan model $1 / 2$, deformasinya cenderung lebih stabil, karena itu peneyerapan energinya lebih besar daripada sambungan $1 / 3$ dan sambungan $1 / 4$.

2. Crash box pada model sambungan 1/2 mempunyai nilai penyerapan energi tertinggi sebasar 5249,726 J. Sedangkan crash box pada model sambungan $1 / 3$ mempunyai nilai penyerapan energi terendah yaitu 3106,027 J, lebih rendah dari nilai penyerapan energi dari crash box model sambungan 1/4 yang dihasilkan sebesar 3886,238 J. Hal ini terjadi karena nilai penyerapan energi pada crash box dipengaruhi oleh force reaction dari gaya yang diberikan oleh crash box sebagai reaksi untuk menahan beban.

3. Pola deformasi dihasilkan cenderung menyerupai pola deformasi yang berbentuk mixed-mode, terkecuali pada crash box model sambungan 1/4.

\section{DAFTAR PUSTAKA}

[1] Badan Pusat Statistik. 2015. Statistik Transportasi Darat 2014. Indonesia : Badan Pusat Statistik.

[2] I Putu Ali Putra. 2014. Mengenal Sistem Keselamatan Pada Mobil. Indonesia.

[3] Velmurugan., dan Muralikanan. 2009. Energy Absorption Characteristics of Annealed Steel Tubes Of various Cross Sections in Static And Dynamic Loading. Latin American Journal Of Solids And Structutres, Volume. 6, $2009: 385-412$.

[4] Wiryosumarto, H., Okumura, T. (1994). Teknik Pengelasan Logam. Jakarta. PT. Pradnya Paramita.

[5] Jatmiko, A. (2014). Pengaruh variasi geometri crash box 2 segmen terhadap kemampuan menyerap energi impak dengan simulasi komputer. Tesis. Malang. Jurusan Teknik Mesin Universitas Brawijaya

[6] J. Tanaskovic., dkk. 2014. Experimental Investigations of The Shrinking Splitting Tube Collision Energy Absorber, Journal Thin - Walled Structures. University of Belgrade, faculty of 
Mechanical Engineering, kralije, marije 16 , belgrade, Serbia

[7] Toksoy, A.K. 2009. Optimization of The Axial Crushing Behavior of Closed-Cell Alumunium Foam Filled Welded 1050 Al Square-Cross Section Crash Boxes. Thesis. Izmir : Izmir Institute of Technology
Berbentuk Tabung 2 Segmen terhadap Kemampuan Menyerap Energi Impak dengan Simulasi Komputer. Jurnal Rekayasa Mesin Vol.5, 2014: 201-207.

[8] Asroni, Moch.Agus Choiron, Anindito Purnowidodo. 2014. Pengaruh Crash Box 